ANNALS, $A A P S S, 479$, May 1985

\title{
The Role of Child Support Insurance in Antipoverty Policy
}

\author{
$B y$ IRWIN GARFINKEL
}

ABSTRACT: This article describes existing child support practice in the United States, giving attention to the establishment and enforcement of parental child support obligations as well as to publicly provided child support benefits. Effects of the current system on alleviating poverty are assessed. The article addresses several questions. Should low-income absent parents be excused from the obligation to support their children? Can child support provide more generous benefits to single-parent families while minimizing incentives for the formation of single-parent families? Should children in single-parent families be aided by a welfare program? What are the problems with the current child support system? Finally, a proposal for a new child support insurance system is described, along with estimates of the costs of the system and its effects on poverty and welfare dependence. The relationship of estimated benefits to costs is promising enough to warrant trying out the new system in selected jurisdictions.

Irwin Garfinkel received his doctorate in social work and economics from the University of Michigan. He has had a joint appointment in the School of Social Work and the Institute for Research on Poverty (IRP) at the University of Wisconsin since 1970. He is a former director of IRP and the current director of Social Work. He has authored numerous books and articles on poverty and income maintenance programs. 
$\mathrm{T}$ HE economic well-being of a large and growing percentage of children in the United States is partly dependent upon the nature of our child support institutions.

As of 1981 approximately one of five children in the United States were potentially eligible for child support in that they were residing apart from a living natural parent. ${ }^{1}$ Nearly one of every two children born today will become eligible for child support before reaching age $18 .^{2}$ Presently the majority of children potentially eligible for child support live in families headed by women. ${ }^{3}$ Approximately half of all children in femaleheaded families are poor. These children and their mothers constitute 30 percent of the poor. ${ }^{4}$ Consequently the role of child support in antipoverty policy is important.

\section{EXISTING PRACTICES}

The current child support system consists of two major parts: the judiciary system, which now establishes the

1. For an explanation of how this estimate was derived, see Irwin Garfinkel and Marygold Melli, Child Support: Weaknesses of the Old and Features of a Proposed New System (Madison, WI: Institute for Research on Poverty, 1982), vol. I, fn. I.

2. See the statistical appendix in Daniel Patrick Moynihan, "Welfare Reform's 1971-72 Defeat: A Historic Loss," Journal of the Institute for Socioeconomic Studies, 6:1-20 (Spring 1981). His estimate applies to children living in singleparent families. Since some of these families result from widowhood, the percentage eligible for child support will be smaller.

3. In Wisconsin, 16 percent of children eligible for support live with their fathers, 24 percent live with their mothers and stepfathers, and 60 percent live in female-headed households.

4. See U.S., Department of Commerce, Bureau of the Census, Characteristics of the Population below the Poverty Level: 1980, Current Population Reports, ser. P-60, no. 133 (Washington, DC: Government Printing Office, 1982), tab. 11. responsibility to pay support, sets the amount of support to be paid, and enforces the obligation of parents to pay support; and the Aid to Families with Dependent Children program (AFDC), commonly called welfare. There are many other parts to this system. District attorneys and jails have very big roles in the lives of some absent parents. Food stamps, Medicaid, and public housing play a large part in the lives of most AFDC beneficiaries.

\section{The judicial system}

The first point to make about child support is that with the important exception of the recent federal enforcement legislation discussed later in this section, child support is strictly a state and local function. Family law is traditionally a province of the states.

In most states, the obligation of absent parents to pay child support is explicitly stated in statute, although in some states the obligation is only implied. ${ }^{5}$ Even where the statutes contain guidelines as to how much support should be paid, the guidelines are very general. For example, in Wisconsin the statute instructs courts to apply the following criteria in determining the amount of child support:

- the financial resources of the child;

- the financial resources of both parents;

- the standard of living the child would have enjoyed had the marriage not ended in annulment, divorce, or legal separation;

- the desirability that the custodian remain in the home as a full-time parent;

5. Harry O. Krause, Child Support in America: The Legal Prospective (Charlottesville, VA: Michie, 1981). 
- the cost of day care if the custodian works outside the home, or the value of custodial services performed by the custodian if the custodian remains in the home;

- the physical and emotional health needs of the child;

- the child's educational needs;

- the tax consequences to each party;

- such other factors as the court may in each individual case determine to be relevant.

In short, the system is characterized by judicial discretion.

Judges in some jurisdictions use a child support obligation schedule, which is similar to a tax table. For example, nearly every county in Michigan uses a schedule in which the absent parent's obligation depends only upon his income and the number of children he is required to support. ${ }^{6}$ But such child support schedules are the exception rather than the rule.

In general, in order to collect overdue child support, the custodial parent not on welfare must take the initiative, usually by bringing a civil contempt charge against the nonpaying parent. The custodial parent can get a judgment for a sum of money that puts her in the position of being a creditor, with various avenues open to her that are open to all creditors, such as garnishment of wages and seizure of property.

In a few states, such as Michigan and Wisconsin, a government agency has the authority to initiate legal action when child support obligations are not met. The Michigan Friend of the Court, founded in 1917, is the oldest such agency. Still, except for welfare cases, in which the state rather than the custodial

6. David L. Chambers, Making Fathers Pay: The Enforcement of Child Support (Chicago: University of Chicago Press, 1979). parent gets the proceeds from child support collections, these government agencies usually do not use this authority unless specifically requested to do so by the custodial parent. In most cases, the burden of collecting overdue support falls on the custodial parent.

Jail is the ultimate sanction for those who do not pay. Thousands of absent fathers are jailed each year in Michigan for failure to comply with child support orders. ${ }^{7}$ There are no data on the prevalence of jailing elsewhere. According to Chambers, jailing works. ${ }^{8}$ That is, when combined with an effective monitoring system, it deters nonpayment. His conclusion is based on the strong association between payment performance and utilization of jails across counties in Michigan. A final point to note is that only a small minority of absent fathers who fail to pay child support are jailed.

The most effective child support enforcement tool is a wage assignment. ${ }^{9}$ A wage assignment is a legal order to the employer of the child support obligor to withhold a specified amount from the employee's wages. Wage assignments are being used more frequently. Wisconsin law now requires that a contingent wage assignment be issued in all cases. The county clerk of courts to whom all child support payments are made has the legal authority to effect the wage assignment once child support payments are 20 days delinquent. In practice, however, the clerk of courts does not pursue delinquencies in welfare cases for three to four months. Moreover, this agency takes no initiative in nonwelfare cases.

The overall performance of the child support system is, to say the least, not

7. Ibid., p. 248.

8. Ibid., pp. 90-104.

9. See Krause, Child Support in America; and Chambers, Making Fathers Pay. 
very impressive. Of those women with children potentially eligible for child support in 1979 , only 59 percent were awarded payments. ${ }^{10}$ For divorced and remarried women, nearly 80 percent had awards, while among separated and never-married women, the figures were 45 percent and 11 percent, respectively. Of those awarded support, only 49 percent received the full amount due them and 28 percent received nothing. Combining the 40 percent who were entitled to nothing with the 28 percent who, although entitled, still received nothing results in more than half of those potentially eligible for child support getting nothing. Only 11 percent of the absent fathers of AFDC children pay any child support. ${ }^{11}$

\section{The AFDC system}

The AFDC program was created by the landmark 1935 Social Security Act. Eligible dependent children included those who lost the earnings of a parent because of death, disability, or absence. In 1961, states were also permitted to provide aid to dependent children whose fathers were unemployed. Originally the program paid benefits only to children, but in 1950 the program was amended to include benefits for the custodial parent. When the program was enacted, most of the children who benefited were orphans. Now the overwhelming majority of the children's mothers are divorced or separated or have never married. Widows

10. U.S., Department of Commerce, Bureau of the Census, Child Support and Alimony: 1978 , Current Population Reports, ser. P-23, no. 112 (Washington, DC: Government Printing Office, 1981).

11. Child Support Enforcement (Washington, DC: Department of Health and Human Services, Office of Child Support Enforcement, 1983), tabs. 10 and $19, \mathrm{pp}, 18$ and 28. constitute less than 2 percent of the AFDC case load.

AFDC is an income-tested, or welfare, program. That is, benefits are confined to those with low income. As a consequence benefit reduction ratestax rates-are high. Prior to 1967 , most states reduced benefits by a dollar for each dollar earned. In 1967, in order to promote work, Congress required states to ignore the first $\$ 30$ per month plus one-third of each additional dollar earned when calculating benefits. In 1982 at President Reagan's request, the Congress limited this work incentive to the first four months. After that, benefits are to be reduced again by a dollar for each dollar of earnings.

Although the AFDC program has been at the heart of the welfare reform controversy, AFDC expenditures-\$12.7 billion in fiscal year 1981 - account for only 17 percent of total welfare expenditures and only 4 percent of total expenditures on income support. ${ }^{12}$

On the other hand, AFDC is the most important public program for children with living absent parents. In 1981, it paid benefits to 11 million custodial parents and children, most of whom were potentially eligible for child support. Most AFDC families also receive food stamps and Medicaid assistance in addition to cash benefits. When all welfare programs are included, probably about half of all welfare expenditures go to families potentially eligible for child support.

\section{AFDC and federal \\ child support enforcement}

As noted earlier, in 1935 most single mothers were widows. As the nature of

12. Irwin Garfinkel, ed., Income-Tested Transfer Programs: The Case For and Against (New York: Academic Press, 1982), p. 12. 
the case load shifted in response to the demographic trends of more divorce, separation, desertion, and out-of-wedlock births, congressional interest in absent fathers grew. Congress enacted the first federal child support legislation in 1950 , requiring state welfare agencies to notify law enforcement officials when a child receiving AFDC benefits had been deserted or abandoned. Further legislation, enacted in 1965 and 1967, allowed states to request addresses of absent parents from the Department of Health, Education, and Welfare and the Internal Revenue Service (IRS) and required states to establish a single organizational unit to enforce child support and establish paternity.

In 1975 Congress added Part D to Title IV of the Social Security Act, establishing the Child Support Enforcement program, sometime referred to as the IV-D program. The states are responsible for running the program. They are reimbursed by the federal government for 75 percent of their costs. In 1980 the law was amended so that the federal government would provide 90 percent of the funding for computerizing the program. The IV-D program is supposed to serve nonwelfare as well as welfare cases. As of 1981 about 17 percent of the IV-D case load was attributable to nonAFDC cases.

The 1975 law authorized use of the IRS to collect child support owed to AFDC beneficiaries. In 1980 use of the IRS extended to non-AFDC families. In 1981, legislation required the IRS to withhold tax refunds when individuals owed child support that was past due.

By fiscal year 1982, IV-D collections amounted to $\$ 1.8$ billion. ${ }^{13}$ Despite the fact that the IV-D program had an and 19. average non-AFDC case load of 1.5 million compared to an average monthly AFDC caseload of 5.5 million, collections for the non-AFDC case load totaled $\$ 1.0$ billion compared to $\$ 0.8$ billion for the AFDC case load.

\section{The current effect of child support on poverty}

Although children living in femaleheaded households are but a subset of all children potentially eligible for child support, our discussion focuses on them because even in the absence of child support, children living in male-headed households are unlikely to be poor. ${ }^{14}$ In 1978,51 percent of female-headed families would have been poor in the absence of private and public child support transfers. ${ }^{15}$ The gap between their income and the income required to lift them out of poverty was $\$ 9.1$ billion. Child support from absent parents reduced the percentage of female-headed households that were poor to 47 and reduced the poverty gap to $\$ 8.0$ billion. AFDC and other cash transfers reduced this percentage to 42 and the poverty gap to $\$ 3.8$ billion. Smeeding's estimates indicate that in-kind transfers further reduce poverty among female heads of families by 16 to 49 percent, depending

14. The biggest omitted group live with their remarried mothers. Only 5 percent of those mothers live in households with incomes below the poverty line. See Bureau of the Census, Child Support and Alimony: 1978, tab. 1.

15. These and other figures in the same paragraph in the text are taken from cross-tabulations I produced from the 1979 Current Population Survey (CPS) Mar.-Apr. match tape. A special child support supplement was conducted in the Apr. CPS and matched to the Mar. CPS. See Bureau of the Census, Child Support and Alimony: 1978 for a description of the data. 
upon which in-kind transfers are counted and how they are valued. ${ }^{16}$

These data give rise to two questions. First, is the current division between private and public child support transfers appropriate with respect to poverty reduction? Second, in what ways can the child support system be altered to increase its effectiveness in reducing poverty?

\section{EVALUATING \\ SELECTED ASPECTS OF \\ THE CURRENT SYSTEM}

In its present operation the child support system follows the line of least resistance in dealing with a number of important moral and economic issues that require an informed consensus. Among these are the questions of whether absent parents who have low incomes should be required to pay child support, how much child support absent parents should be expected to pay, whether single-parent families should be treated differently from intact families, and whether welfare is the most appropriate way to aid poor children.

\section{Should low-income absent parents be required to pay child support?}

A fundamental principle that is consistent with current law and common belief and underlies both our evaluation of the current child support system and our efforts to reform the system is that when an individual parents a child, that individual incurs an obligation to share his or her income with the child. Yet most absent parents and the overwhelming majority of absent parents with low

16. See Timothy Smeeding, Alternative $M e$ thods for Valuing Selected In-Kind Transfer Benefits and Measuring Their Effects on Poverty, Technical Paper no. 50 (Washington, DC: Department of Commerce, Bureau of the Census, 1982), p: 89. income pay no child support. Are there good reasons for exempting low-income absent parents from the obligation to pay child support? Two arguments have been advanced for doing so.

First, there is the argument that lowincome absent fathers cannot afford to pay child support. Many are unemployed. Many remarry. Enforcing support will only impoverish and pauperize the new family as well as the old.

The best data indicate that the average income in 1980 of an absent father with a child receiving AFDC in Wisconsin was nearly $\$ 11,000 .{ }^{17}$ Clearly, absent-parent income is nonnegligible.

A second question is, How much of the absent father's income should be transferred to his children? Should some of his income be set aside for his own living expenses? Should additional funds be set aside for a new wife and children? If so, how much? Those who argue that most absent fathers of welfare children cannot afford to pay child support believe that the absent father should not be required to pay any support until his income is high enough to provide a relatively decent standard for himself and a new family. According to the standards developed by the Community Council of New York, absent fathers need income close to the median level of income to be able to afford to pay child support. $^{18}$

In contrast, under a standard developed by the Wisconsin Department of Health and Social Services (DHSS),

17. See Thomas McDonald, James Moran, and Irwin Garfinkel, Wisconsin Study of Absent Fathers' Ability to Pay Child Support, Institute for Research on Poverty Special Report no. 34 (Madison, WI: Institute for Research on Poverty, 1983).

18. See Guide for Determining the Ability of an Absent Parent to Pay Child Support (New York: Community Council of Greater New York, 1981). 
noncustodial fathers should pay 17 percent of their income to support one child, 25 percent to support two children, 29 percent, 31 percent, 32 percent, and 33 percent for three, four, five, and six or more children, respectively. If absent fathers of AFDC children paid child support according to the Wisconsin DHSS standard, their total contribution to child support would be $\$ 5.1$ billion. Although many fewer absent fathers would pay anything under the Community Council of New York's guidelines, those who paid would pay much more than under the Wisconsin DHSS formula and, based on results for Wisconsin, the aggregate amount paid would be higher than $\$ 5.1$ billion. ${ }^{19}$ Both figures should be contrasted with the $\$ 0.7$ billion currently collected.

The second argument for exempting low-income absent fathers from paying child support is that the costs of collecting the payment are too high. For the United States as a whole, the ratio of AFDC child support collections to collection costs is only $\$ 1.30$ to $\$ 1.00$. Moreover in 22 states, costs exceed collection. ${ }^{20}$ The record of the existing system is hardly promising. If one believes strongly enough in enforcing parental responsibility, one can always make a case that even if costs exceed collections, the extra costs are justified. Few, however, are so fervently committed. Indeed, most of us would expect to do a good bit better than spending $\$ 1.00$ to raise $\$ 1.30$. Consequently, unless the system can be made far more efficient than it is currently, there may be some justification

19. See Donald T. Oellerich, The Effects of Potential Child Support Transfers on Wisconsin AFDC Costs, Caseloads and Recipient WellBeing, Institute for Research on Poverty Special Report no. 35 (Madison, WI: Institute for Research on Poverty, 1984) p. 140.

20. Child Support Enforcement, p. 83. for excusing low-income absent fathers from the obligation to pay child support.

Two historical experiences suggest that automatic universal wage withholding of child support obligations might make the collection of child support from low-income absent fathers sufficiently efficient to justify the effort. First, until the enactment of the Social Security payroll withholding tax, income tax experts believed that it was impossible to collect from low-income families. Second, current experience with wage withholding in child support is very promising.

\section{Child support as a resolution}

to the dilemma of categories

In the previous section, some arguments for excusing low-income absent parents from the obligation to pay child support were considered. In this section, an argument is advanced that enforcing the child support obligations helps resolve a dilemma of categorization in income support systems. Categorization consists of treating different groups differently, for example, treating one-parent families differently from two-parent families.

The general case for categories is that their use improves the trade-off between adequacy and cost. ${ }^{21}$ If some groups are more likely than other groups to be poor, the costs of forgoing categorization are high. Either the benefits provided to all are high enough for the group with the greatest needs, in which case the system will be quite expensive, or the benefits, although sufficient for those with the fewest needs, are insuf-

21. See G. A. Akerlof, "The Economics of Tagging," American Economic Review, 68:8-19 (Mar. 1978); and Alton Linford, "Public Assistance Categories: Yes or No?" Social Service Review, 22:199-210 (June 1948). 
ficient for those with the greatest needs. The general problem with categories is that they create incentives for people to change their behavior in order to fit into the more favored category.

The rationale for providing more aid to single-parent than to two-parent families is that the gap between needs and the ability to meet those needs is greater in single-parent families. In such families there is only one adult capable of generating income, caring for the children, and doing housework. Furthermore, in the overwhelming majority of cases, the single parent is a woman and therefore is paid much less than a man with comparable years of schooling. In a study Robert Haveman and I conducted, we found that female-headed families were just as likely to be poor if families were ranked by their earnings capacityability to generate income if the adults worked full-time all year-as by actual income. $^{22}$

The problem with provioing more aid to single-parent families is that doing so creates incentives for the formation and preservation of single-parent families. Although several research studies have found a positive correlation between the level of AFDC benefits and the prevalence of female headship in the United States, other studies find no effect. Taken together these studies suggest that the effect is probably weak. ${ }^{23}$ The strongest effect of AFDC benefits appears to be discouragement or delay of remarriage.

Of course, it is possible that society is better off-or at least not worse off-as.

22. Irwin Garfinkel and Robert Haveman, Earnings Capacity, Poverty, and Inequality (New York: Academic Press, 1977), chap. 4.

23. See John Bishop, "Jobs, Cash Transfers, and Marital Instability: A Review and Synthesis of the Evidence," Journal of Human Resources, 15: 301-34 (Summer 1980); and Robert Hutchens, "Welfare, Remarriage, and Marital Search," American Economic Review, 69:369-79 (June 1979). a result of whatever additional singleparent families are created by more favorable treatment of those groups. Not all marriages are made in heaven. Some men beat their wives and children. In some of these cases, all the parties may be better off separate rather than together. Although the most reliable research indicates that boys who grow up in single-parent families do less well than boys who grow up in two-parent families, this research may not be a good guide to policy. ${ }^{24}$ For these families are likely to differ in other ways besides the number of parents present. ${ }^{25}$

Despite the fact that increases in single parenthood may not be socially pernicious, prudence would suggest that in the face of ignorance we should seek to minimize incentives for single parenthood. In any case, most public finance experts believe that tax and transfer policy should be designed to be neutral with respect to behavioral choices.

Income transfer policy is confronted with the following dilemma. How can single-parent families be aided more generously without creating incentives for the formation of such families? Child support can help resolve the dilemma. If the more generous aid to single-parent families is paid for or financed by the absent parent, the total incentive for breaking up a family is reduced. Placing the cost on the absent parent deters him from leaving the family, although it does not directly increase the cost of separation to the custodial parent.

24. For an excellent review of the literature and the best study to date, see Sara McLanahan, "Family Structure and the Reproduction of Poverty," American Journal of Sociology (in press).

25. For example, it is possible that bad family life leads both to divorce and to long-term harm to the children. In this case the children of singleparents would be expected to do less well than children in two-parent families even if being in a single-parent family had no effect. 


\section{Should children in}

single-parent families be

aided by a welfare program?

Strong arguments exist for supplementing the incomes of those who are expected to work through nonwelfare programs. Since female heads of families are increasingly expected to work - and indeed do work - welfare programs are not the best way to aid them.

The incomes of those expected to work can be supplemented either by programs designed only to aid those with low income - income-tested or welfare programs--or by programs designed to aid all regardless of income-nonincome-tested programs. AFDC and Food Stamps are examples of incometested programs; children's allowances and public education are examples of non-income-tested programs. First, we must dispose of the frequently heard argument that welfare programs are more efficient than nonwelfare programs. ${ }^{26}$ Welfare programs reduce benefits as income increases, which is equivalent to taxing income. Compared to the tax rates they face in welfare programs, the tax rates that the poor must pay to finance programs that provide the same benefits to all-regardless of income-will be lower. On the other hand, in order to finance a non-incometested program that provides the same benefits as an income-tested program, tax rates on the nonpoor must be higher. So whether income testing is efficient or not depends upon whether it is more efficient to place higher tax rates on the rich or the poor. The limited empirical evidence available does not support the

26. See, for example, C.L. Schultze et al., Setting National Priorities: The 1973 Budget (Washington, DC: Brookings Institution, 1972), p. 200 . claim that income testing is more efficient and, indeed, leans the other way. ${ }^{27}$

Equity considerations strengthen the case for using non-income-tested programs to aid those expected to work. By their nature welfare programs impose tax rates on beneficiaries that are higher than the tax rates imposed on nonbeneficiaries to finance the program. This is equivalent to imposing a regressive marginal tax rate structure in our overall tax-transfer system.

Because the tax rates in our taxtransfer system are regressive, they penalize poor people for working to a greater degree than the tax system penalizes the rest of us. The economic component of this is that we reduce the relative incentive of the poor to work. The moral component is that we stack the deck against their making it the way Americans are supposed to make it-through work. The poor have the worst jobs and get paid the least. If we really want them to work they should face the lowest, not the highest, tax rates.

Granted that welfare programs are not the best way to supplement the incomes of those expected to work, should female heads of families be classified as expected to work? When the AFDC program was enacted in 1935,

27. Two of the three studies that address the issue specifically conclude that non-income-tested programs are more efficient. These two are superior theoretically to the third, which finds the opposite. On the other hand, the third is superior in some dimension in terms of its empirical methodology. See J. R. Kesselman and Irwin Garfinkel, "Professor Friedman, Meet Lady Rhys-Williams: NIT vs. CIT," Journal of Public Economy, 10:179-216 (1978); Efraim Sadka, Irwin Garfinkel, and Kemper Moreland, "Income Testing and Social Welfare," in Income-Tested Transfer Programs, ed. Garfinkel, chap. 8; and David Betson, David Greenberg, and Richard Kasten, "A Simulation Analysis of the Economic Efficiency and Distributional Effects of Alternative Program Structures," in ibid., chap. 6 . 
women were not expected to work. Moreover, we were in the midst of the Great Depression; the program was designed to enable single mothers to stay home to raise their children. Now that half of married women with children work, expectations have changed. A new consensus is emerging. Single mothers are increasingly expected to work. Indeed, in view of the fact that threefourths of single mothers do work, the value judgment required to decide whether they should be expected to work may be beside the point.

\section{Summary critique of \\ the current system}

Throughout the country, the current child support system condones and therefore fosters parental irresponsibility. It is inequitable and therefore exacerbates tensions between former spouses. And everywhere the system impoverishes children.

Parental irresponsibility is evidenced in the national statistics already presented. To summarize, less than half of absent fathers pay any child support.

The child support system is inequitable because whether the absent parent is ordered to pay support, how much he is ordered to pay, and how much effort is devoted to forcing him to pay depend not just on ability to pay, but on the varying attitudes of local judges, district attorneys, welfare officials, and the skills of the parents' lawyers. Nearly every absent parent can find someone earning more who pays less. Nearly every custodial parent knows someone who is receiving more from an absent father who earns less. Because of this and the absence of firm, determinative legislative guidelines, child support is a major source of continuing tension between many former spouses.
Finally, the widespread failure of the system to ensure that absent parents pay child support impoverishes children and shifts the burden of financial support to the public sector. Nearly half of all children living in female-headed households are poor and on welfare. Yet, as suggested earlier, in view of the fact that so many single mothers work, welfare is no longer the best way to aid children with single mothers.

\section{CHILD SUPPORT INSURANCE}

In view of these problems with the current child support system, a research team from the Institute for Research on Poverty, under contract with the Wisconsin DHSS, has developed a proposal for a new child support insurance system. $^{28}$

Under the program all parents who live apart from their children are liable for a child support tax. The base for the tax will be gross income. The rate will be proportional and depend upon the number of children owed support. For example, the tax rate might be 17 percent for one child, and $25,29,31,32$, and 33 percent for two, three, four, five, and six or more children, respectively. The child support tax would be collected through a wage-withholding system, like payroll and income taxes. All children with a living absent parent would be entitled to a child support benefit equal to either the child support tax paid by the absent parent or a socially insured minimum benefit, whichever is higher. In cases where the absent parent pays less than the minimum, the difference would be financed out of general revenues now devoted to the AFDC program. Finally, in cases where the absent parent pays less than the minimum, the custodial

28. Garfinkel and Melli, Child Support. 
parent would be subject to a surtax up to the amount of the public subsidy.

A few words about the rationale for three major features of this new system are warranted. First, why establish child support obligations by legislation rather than judicial discretion? The principal argument is that because of the large financial obligation already borne by the state, the apportionment of support for poor children among the custodial parent, the absent parent, and the public is more appropriately a legislative function. Moreover, a legislated formula would reduce inequity. Finally, the use of courts is too costly to society and the families affected.

Second, why use general revenues to supplement inadequate child support payments from absent parents? Doing so will insure children against the risk that their noncustodial parent's income declines or is permanently low. It will also reduce welfare costs and case loads.

Third, why treat child support as a tax and use the withholding system in all cases? Because wage withholding is the most effective collection tool we have, and effective and efficient collection of child support is essential.

The new child support benefit tax program would achieve the objectives of

-assuring that those who parent children share their income with them;

—establishing and collecting child support equitably and efficiently;

-increasing the economic well-being of children who have a living absent parent, while

- simultaneously reducing welfare costs and case loads.

How much would a child support insurance program cost? And how much would it reduce poverty and welfare dependence?
Both the benefits and the costs of a child support insurance program will depend upon the level of the minimum benefit, the tax rates on noncustodial and custodial parents, and the effectiveness of child support collections. In Table 1 estimates of net savings, or costs, and reductions in poverty and AFDC case loads are presented for child support insurance programs with four different minimum benefit levels. The minimum benefits for the first child range from $\$ 2000$ to $\$ 3500$. Minimum benefits for the second, third, fourth, fifth, and sixth child are equal to $\$ 1500$, $\$ 1000, \$ 500, \$ 500$, and $\$ 500$, respectively. The tax rates for noncustodial parents are 17 percent for one child, 25 percent for two children, 29 percent for three children, 31 percent for four children, 32 percent for five children, and 33 percent for six or more children. Tax rates for custodial parents are equal to one-half those for noncustodial parents. The estimates in the top panel of Table 1 assume 100 percent collection effectiveness.

The most striking finding is that if we collect 100 percent of the noncustodial parents' child support obligation, three of the four child-support insurance programs would actually save money. That is, the extra dollars paid out under the new program would be more than offset by increased child support collections and consequent reductions in welfare expenditures. Even the most generous plan costs less than a quarter of a billion dollars.

At the same time, all the programs would reduce the poverty gap, the difference between the income of a poor family and the income the family would need to reach the poverty line. The number of families on welfare would be reduced as well. The reductions in the poverty gap for families eligible for child 
support are quite large, ranging from a low of 39 percent to a high of 53 percent. Similarly, reductions in welfare case loads are very large, ranging from 48 to 64 percent. ${ }^{29}$ In short, all of the child support insurance programs would substantially reduce poverty and welfare dependence and three of four would actually save money.

29. Actually, the welfare case-load reductions are too high because they are based on annual data whereas eligibility is based on monthly income. On the other hand, they are too low because they do not take account of the increases in work that would result from the improved incentives of a child support insurance program.
No matter how efficient the collection system is, less than 100 percent of potential revenue will be collected. Consequently, the second and third panels in Table 1 present estimates of the effects of collecting only 80 percent and 70 percent, respectively, of the noncustodial parents' child support obligation. If we collected only 80 percent of potential revenue, the $\$ 2500$ minimum benefit plan would still save $\$ 0.59$ billion. But the $\$ 3000$ minimum benefit plan instead of saving $\$ 0.87$ billion - as with 100 percent collection-costs an additional $\$ 0.33$ billion. If we collect only 70 percent of potential revenue, both plans

TABLE 1

ESTIMATED COSTS OR SAVINGS AND EFFECTS ON POVERTY AND AID TO FAMILIES WITH DEPENDENT CHILDREN (AFDC) CASE LOADS OF ALTERNATIVE CHILD SUPPORT INSURANCE PROGRAMS IN 1983 DOLLARS

\begin{tabular}{|c|c|c|c|}
\hline $\begin{array}{l}\text { Minimum Benefit } \\
\text { Level for First Child }\end{array}$ & $\begin{array}{c}\text { Net Savings } \\
\text { or Costs } \\
\text { (billions) }\end{array}$ & $\begin{array}{l}\text { Reduction } \\
\text { in Poverty Gap }\end{array}$ & $\begin{array}{l}\text { Reduction } \\
\text { in AFDC } \\
\text { Case Loads }\end{array}$ \\
\hline
\end{tabular}

100 Percent Collection Effectiveness

$\begin{array}{rrll}\$ 2000 & \$ 2.37 & 39 \% & 48 \% \\ 2500 & 1.72 & 43 & 54 \\ 3000 & 0.87 & 48 & 59 \\ 3500 & -0.18 & 53 & 64\end{array}$

80 Percent Collection Effectiveness

$\$ 2500$ 3000

$\$ 2500$ 3000

\section{$\$ 0.59$}

$-0.33$
$40 \%$

45
$49 \%$

56

70 Percent Collection Effectiveness

$\begin{array}{rll}\$-0.06 & 38 \% & 48 \% \\ -1.83 & 43 & 54\end{array}$

NOTE: The estimates are derived from the "1979 Current Population Survey-Child Support Supplement" (CPS-CSS). The CPS-CSS is a match file that contains data from both the March annual demographic and income survey and the April 1979 child support supplement. On the basis of the March survey 3547 women who were eligible to receive child support were identified and interviewed in April. In order to estimate savings or costs and reductions in poverty and AFDC case loads, it was necessary to impute noncustodial parent incomes. Estimates of the noncustodial fathers' income are derived from regressions relating wives' characteristics to husbands' incomes. For a more detailed description of the data and methodology, see Donald Oellerich and Irwin Garfinket, "Distributional Impacts of Existing and Alternative Child Support Systems," Policy Studies Journal, 12(1): 119-29 (Sept. 1983). 
cost more, although the extra cost of the $\$ 2500$ plan is very small. Note also that collecting less than 100 percent of the noncustodial parent obligation also reduces the effectiveness of a child support insurance program in reducing poverty and welfare dependence. These effects are not so large as the effect on costs, however, because for poor families the minimum benefit makes up for most of the loss in private child support.

\section{WHITHER THE FUTURE?}

In summer 1984 the Congress voted unanimously to enact the strongest federal child support legislation to date. The legislation requires all states to (1) initiate a process to withhold child support from the wages of noncustodial parents who are delinquent in their child support payments for one month; and (2) appoint blue-ribbon commissions to devise statewide standards for child support. In addition, for the first time the law gives financial incentives for states to collect child support for non-AFDC cases and out-of-state cases. The provisions for wage withholding and statewide standards move the country in the direction of the child support insurance proposal. But withholding in response to delinquency is not likely to be nearly as effective as universal withholding. Does anyone imagine that income and payroll tax collections would be as high if we withheld them only for delinquents? Similarly because the statewide standards will not be binding upon-and therefore can be ignored by-local judges, they will be less effective than legislated standards.

The state of Wisconsin is currently conducting a demonstration to evaluate a child support insurance program. Currently 10 counties are using income withholding in all new cases. The state Department of Health and Social Services at the direction of the state legislature has published a child support standard with withholding rates of 17 percent for one child, 25 percent for two children, and so on, which judges may but are not required to use in determining the support obligation. Finally, the 1984 federal child support legislation contains a provision that gives Wisconsin authority to use AFDC funds to help finance the minimum benefit in the child support insurance demonstration. Intensive planning for conducting the benefit side of the demonstration is now under way and implementation is scheduled for early 1987.

The contrast between the dismal reality of the current child support system and the bright promise of a child support insurance system warrants experimentation with the latter. Whether a child support insurance program will be as attractive in practice, of course, remains to be seen. 